\title{
The Amelioration of Reclamation on Physical and Chemical Properties of Coastal Saline-Sodic Soils
}

\author{
Lianhui Shi, Yufei Zhu, Peidong Li, Xiliang Song* \\ College of Resources and Environment, Shandong Agricultural University, Tai'an, Shandong, China, 271018
}

Received: 22 December 2020

Accepted: 8 May 2021

\begin{abstract}
Poor soil quality caused by salinity and sodicity is the main limitation on plant growth and crop production worldwide. This study focused on the change in the physicochemical properties of the coastal saline-sodic soils of Yellow River Delta with different histories of reclamation. Soil samples representing six different reclamation times (RTs) were collected in two soil profiles $(0-20 \mathrm{~cm}$ and $20-40 \mathrm{~cm})$. The results showed that soil soluble salts (SSs) significantly decreased with increasing reclamation time, and the change were $32.9 \%-67.6 \%$ in the $0-20 \mathrm{~cm}$ layer and $39.0 \%-73.2 \%$ in the $20-40 \mathrm{~cm}$ layer, respectively. Based on non-liner fitting, the change regulation of SS with RT was expressed by the following functions: $\mathrm{SS}=-222.9+\frac{225.8}{1+\left(\frac{\mathrm{RT}}{1.34 \times 10^{7}}\right)^{0.3}}\left(\mathrm{R}^{2}=0.93, p<0.01\right)$ in the $0-20 \mathrm{~cm}$ layer and $\mathrm{SS}=$ $0.82+\frac{4.48}{1+\left(\frac{\mathrm{RT}}{10.6}\right)^{1.57}}\left(\mathrm{R}^{2}=0.97, p<0.01\right)$ in the $20-40 \mathrm{~cm}$ layer, respectively. The other soil properties, such as bulk density, total carbon, total nitrogen, the ratio of carbon and nitrogen, soil organic matter, available phosphorus, and available potassium significantly improved with increasing RT, but EC and $\mathrm{pH}$ had the opposite trend. The change in the physical and chemical properties of saline-sodic soil was higher at $0-20 \mathrm{~cm}$ soil depth than at the $20-40 \mathrm{~cm}$ soil depth, indicating that the effect of reclamation on salinesodic soils occurs mainly in topsoil. In conclusion, reclamation has been shown to be an effective human activity in terms of improving fertilizer and inhibiting the salinity of saline-sodic soils.
\end{abstract}

Keywords: soil restoration, coastal saline wasteland, soil properties, soil salt and fertilizer

\section{Introduction}

Soil degradation caused by salinity and sodicity has been proven to be a major adverse limitation on sustainable agricultural development and crop production stabilization [1]. Saline-alkaline land is

*e-mail: sx10424@126.com

usually characterized by poor macronutrient availability, high soil salinity, intermittent drought, changing temperatures, and an unstable sandy substrate [2]. The lands within coastal areas are always accompanied by high soil salinity and shallow groundwater with high mineralization [3]. Saline-sodic soils and high salinity groundwater have several effects on vegetation, such as hindering the germination and growth of plants $[4,5]$, and causing physiological drought in plants [6], cell toxicity [7], nutrient imbalance [8], and 
so on [9]. In recent years, improper irrigation and other anthropogenic activities have aggravated soil salinization, resulting in an increase in soil infertility [10]. Although lots of experiments have been conducted on saline-sodic soil restoration, the lack of appropriate and effective measures to control the high levels of salt in the soil makes coastal saline-alkaline lands difficult to exploit and utilize [11, 12].

Reclamation has been proved to be an effective way to improve soil quality in various areas [13-15]. Theoretically, two steps are needed to perform salinesodic soil reclamation. The first step is dislodge $\mathrm{Na}^{+}$ from the cation exchange sites in the soil colloid, and the second step is leaching out the replaced $\mathrm{Na}^{+}$ in the plant root zone [16]. The reclamation of saltaffected soils through tillage, irrigation, vegetation, and amendment practices is an increasingly useful tool for the improvement of crop productivity. Several studies have reported that reclamation over time has a positive effect on soil quality evolution [17, 18]. As physicochemical characteristics are the main indicators of soil quality [18, 19], knowledge about the dynamics of physical and chemical characteristics during reclamation is particularly important for guiding future ecological restoration $[20,21]$.

The Yellow River Delta, which is the largest and youngest coastal estuary wetland in China, encompasses the areas along the Lower Yellow River, especially in the estuary formed by a large amount of sediments carried by the Yellow River [22]. The Yellow River Delta plays an important role in global ecosystem because it provides an indispensable staging, wintering and breeding site for birds the around Pacific migration route [23]. However, it experiences primary and secondary salinization because of the shallow saline groundwater and high evaporation rates as well as human activities. The salinity of this area threatens food production and the environment [24]. Previous studies have focused on wetland and mined land restoration after reclamation, but coastal saline-sodic lands with different reclamation histories in Yellow River Delta has not yet been studied. In this study, we focused on the physicochemical properties of reclaimed salinesodic soils in two soil profiles $(0-20 \mathrm{~cm}$ and $20-40 \mathrm{~cm}$ depth) in the Yellow River Delta. The main objectives of our study were to: (1) compare the differences in soil properties between reclaimed saline-sodic soils and natural soils (unutilized land) in two soil profiles (0-20 $\mathrm{cm}$ and 20-40 cm depth); (2) analyse the influences of time since land reclamation (reclamation time) on soil properties; and (3) identify the relationships between the soil properties of the various soil layers of the profile.

\section{Materials and Methods}

The study was conducted in the Yellow River Delta located in Shandong Province, China (Fig. 1). The area has a north subtropical marine monsoon climate according to Koppen's classification. The area has a clear distinction between the four seasons of the year. Its mean annual average evaporation, mean annual precipitation and mean annual temperature is approximately $1982 \mathrm{~mm}, 552 \mathrm{~mm}$ and $12^{\circ} \mathrm{C}$, respectively [25]. The dominant natural plant species are Phragmites australis, Suaeda salsa and Tamarix chinensis. Dominant crops are maize (Zea mays L.), wheat (Triticum aestivum) and cotton (Gossypium hirsutum).

In our experiment, six sites (Fig. 1) with various reclamation years were selected in August 2016. RT0 represents a natural soil that has never been disturbed by human. RT5, RT10, RT15, RT27 and RT36 represents the soils that have been reclaimed to farmlands by farmers for 5, 10, 15, 27 and 36 years, respectively. The description of normal agricultural management practices on the reclaimed farmlands is shown in Table 1. The soil type in the study sites could be

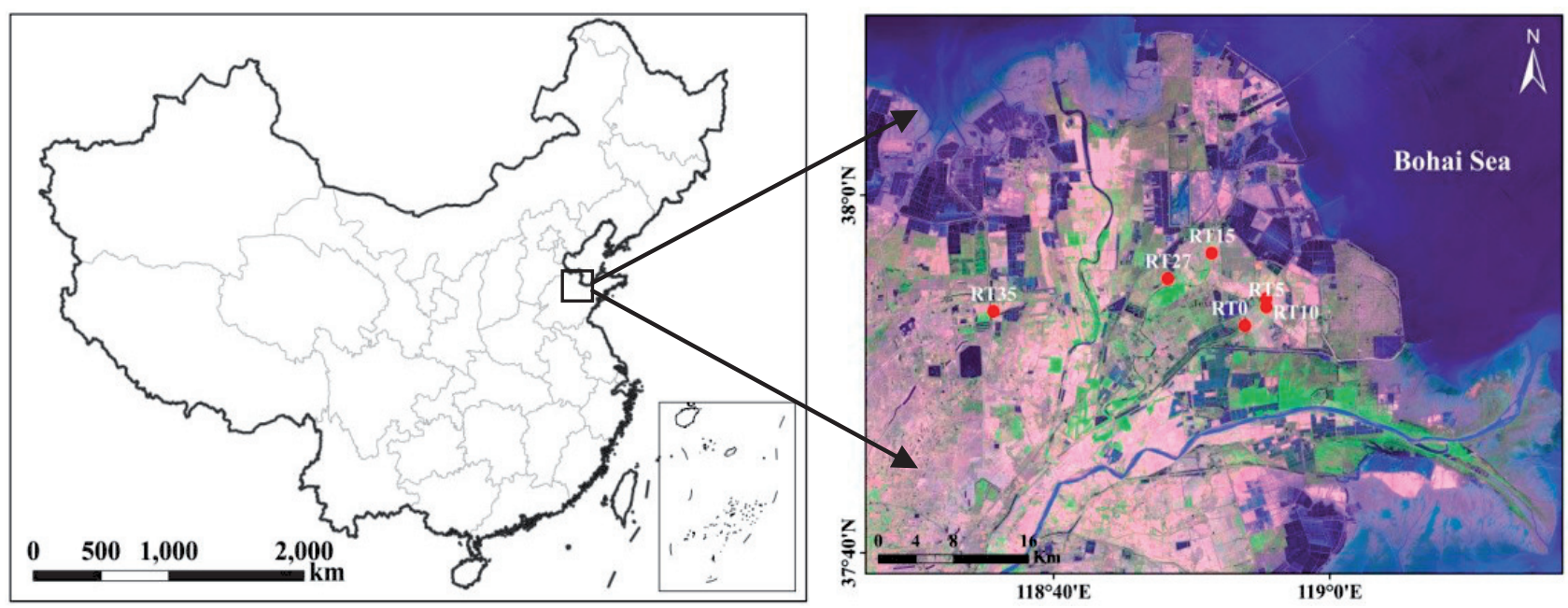

Fig. 1. Map of six sampling sites in Yellow River Delta. RT0 - 0 year reclamation (unutilized land); RT5 - 5 years reclamation; RT10 - 10 years reclamation; RT15 - 15 years reclamation; RT27 - 27 years reclamation; RT36 - 36 years reclamation. 
Table 1. Details of normal Agricultural management practices for the experimental fields.

\begin{tabular}{|c|c|c|c|c|c|c|c|}
\hline $\begin{array}{l}\text { Reclamation } \\
\text { years }\end{array}$ & \multicolumn{3}{|c|}{ Type of crop cultivation } & \multicolumn{2}{|c|}{$\begin{array}{l}\text { Mean groundwater depth } \\
\qquad(\mathrm{m})\end{array}$} & \multicolumn{2}{|c|}{$\begin{array}{c}\text { Average groundwater mineralization } \\
\text { degree }\left(g \cdot \mathrm{L}^{-1}\right)\end{array}$} \\
\hline 5 (RT5) & \multicolumn{3}{|c|}{ Wheat and maize continuous cropping } & \multicolumn{2}{|c|}{$0.96 \pm 0.06$} & \multicolumn{2}{|c|}{$9.40 \pm 0.36$} \\
\hline 10 (RT10) & \multicolumn{3}{|c|}{ Wheat and maize continuous cropping } & \multicolumn{2}{|c|}{$1.36 \pm 0.13$} & \multicolumn{2}{|c|}{$7.94 \pm 0.52$} \\
\hline 15 (RT15) & \multicolumn{3}{|c|}{ Wheat and maize continuous cropping } & \multicolumn{2}{|c|}{$0.85 \pm 0.06$} & \multicolumn{2}{|c|}{$10.21 \pm 0.57$} \\
\hline 27 (RT27) & \multicolumn{3}{|c|}{$\begin{array}{l}\text { Wheat and c maize continuous cropping } \\
\text { (Maize monoculture in the last two years) }\end{array}$} & \multicolumn{2}{|c|}{$1.30 \pm 0.10$} & \multicolumn{2}{|c|}{$6.51 \pm 0.38$} \\
\hline 36 (RT36) & \multicolumn{3}{|c|}{ Wheat and maize continuous cropping } & \multicolumn{2}{|c|}{$1.14 \pm 0.09$} & \multicolumn{2}{|c|}{$8.42 \pm 0.53$} \\
\hline \multirow{2}{*}{$\begin{array}{l}\text { Reclamation } \\
\text { years }\end{array}$} & \multicolumn{2}{|c|}{ Irrigation application } & \multicolumn{2}{|c|}{ Machine Plowing } & \multicolumn{2}{|c|}{ Base fertilizer application } & \multirow{2}{*}{$\begin{array}{l}\text { Top dressing } \mathrm{N} \text { fertilizer } \\
\text { application rate } \\
\left(\mathrm{Kg} \mathrm{N} \cdot \mathrm{ha}^{-1} \cdot \mathrm{a}^{-1}\right)\end{array}$} \\
\hline & Date & $\begin{array}{l}\text { Rate } \\
(\mathrm{mm})\end{array}$ & Date & $\begin{array}{l}\text { Depth } \\
(\mathrm{cm})\end{array}$ & Date & $\begin{array}{c}\text { Rate } \\
\left(\mathrm{Kg} \cdot \mathrm{ha}^{-1} \cdot \mathrm{a}^{-1}\right)\end{array}$ & \\
\hline 5 (RT5) & April & $300-400$ & June and October & $20-40$ & June and October & 1020 & 450 \\
\hline 10 (RT10) & April & $300-400$ & June and October & $20-40$ & June and October & 900 & 520 \\
\hline 15 (RT15) & April & $300-400$ & June and October & $20-40$ & June and October & 1100 & 400 \\
\hline 27 (RT27) & April & $250-350$ & June and October & $20-40$ & June and October & 1210 & 400 \\
\hline 36 (RT36) & April & $250-350$ & June and October & $20-40$ & June and October & 1245 & 390 \\
\hline
\end{tabular}

Base fertilizer was applied as compound fertilizer (N-P-K: 12-19-13) in sowing period of wheat and maize season.

Top dressing fertilizer was applied as urea fertilizer including $46.0 \% \mathrm{~N}$.

The data of fertilizer application amount was from the investigation of farmers.

classified as salinized fluvo-aquic soil and the soil texture is mainly sandy clay loam [26]. Four sampling points (a $1000 \mathrm{~m} \times 1000 \mathrm{~m}$ square) were randomly selected to collect soil samples from depths of $0-20 \mathrm{~cm}$ and $20-40 \mathrm{~cm}$ at each sampling site. At each sampling point, five subsamples within a $100 \mathrm{~m}$ radius were collected and merged into one composite sample. In total, 40 reclaimed wetland soils and 8 natural wetland soils were collected. The soil samples were put in polyethylene boxes and then brought back to the laboratory. After air-drying at room temperature (approximately $27^{\circ} \mathrm{C}$ ) for two weeks, the soil samples were sieved through a $2 \mathrm{~mm}$ nylon sieve to move coarse debris, plant roots, sand and stones. The air-dried samples were separated into two parts. The two parts of the soils were ground in different mortars until all particles passed through a $2.0-\mathrm{mm}$ sieve for physical analysis and a $1.5-\mathrm{mm}$ sieve for chemical analysis, respectively.

All samples were analysed for soil physical and chemical properties. Bulk density (BD) was analyzed with the cutting ring method [27]. The soil salt (SS) content was determined by the residue drying method [24]. Soil $\mathrm{pH}$ was measured using a $\mathrm{pH}$ meter (PB-10, Sartorius, Germany) at a soil: water ratio of 1:5 [28]. Electrical conductivity (EC) was measured using a conductivity meter (DDS-307, Leizi, China) in the supernatants of 1:5 soil-water mixtures. The soil organic matter (SOM) concentration was analysed by potassium dichromate oxidation titration [29]. Total carbon (TC) and total nitrogen (TN) content were measured using an automatic Elemental Analyzer
(Chnos Elemental Analyzer, Vario EL, Germany) [12]. Available phosphorus (AP) and available potassium (AK) were measured using the Olsen method [13] and flame emission spectrometry [30], respectively.

All data were obtained from the average of four replicas. Means and standard errors were calculated for the soil characteristics for both reclaimed salinesodic soils and natural soils. All statistical tests were considered to be significant if $p<0.05$, and Duncan pairwise analysis was adopted to analyse significant differences. A correlation matrix was prepared to identify relationships among soil properties in both reclaimed and undisturbed sites. Trend lines generated by multiple linear regressions were used to simulate the general trend of soil salts changing with reclamation histories in the profile. One-way ANOVA was also used to test the differences in trend lines and the means of soil characteristics. A Pearson's correlation matrix among soil characteristics for the reclaimed saline-sodic soils was constructed. All statistical analyses were performed using SPSS 19.0 (SPSS Inc. Chicago, USA). Pictures were conducted by Origin 9.0 (Origin Lab Inc., MA, USA) and R Programming Language 3.4.2 (University of Auckland, New Zealand).

\section{Results}

\section{Soil Soluble Salt Contents}

The change in SS contents under different reclamation times are shown in Fig. 2. At the $0-20 \mathrm{~cm}$ 


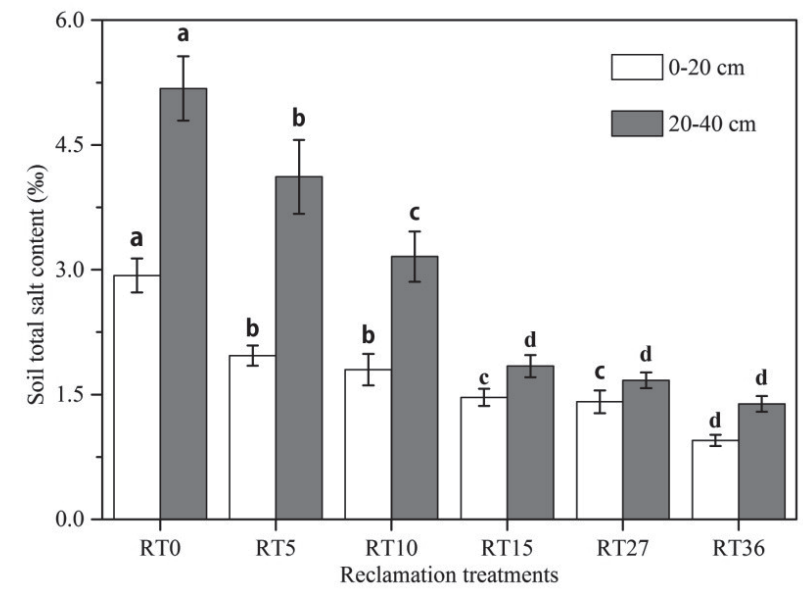

Fig. 2. Change of saline-sodic soil soluble salts at different reclamation treatments. Vertical bars represent $\pm \mathrm{SD}$ of the mean $(\mathrm{n}=4)$; Different letters on the SD bars indicate significant differences among the treatments $(p<0.05)$.

soil depth, the soil total content of RT0 reached 2.93\%o, indicating that the RT0 sample was very typical in the Yellow River Delta. With the increase in RT, the SS values continued to decrease, and of the treatments, RT36 had the lowest SS value $(1.97 \%$ ), which was reduced by $67.6 \%$, compared to that of RT0. The SS content at the $20-40 \mathrm{~cm}$ soil depth was much higher than that at the $0-20 \mathrm{~cm}$ soil depth, but the effect of reclamation at the $20-40 \mathrm{~cm}$ soil depth was similar to that at the $0-20 \mathrm{~cm}$ soil depth. The results showed that compared to RT0 at $20-40 \mathrm{~cm}$ soil depth, the SS contents of RT5, RT10, RT15, RT27 and RT36 decreased by $20.5 \%, 39.0 \%, 64.4 \%, 67.7 \%$ and $73.2 \%$, respectively. According to the variance analysis (Table 2), RT had an significant effect on SS $(p<0.01)$.

\section{Soil Electric Conductivity, $\mathrm{pH}$ and Bulk Density}

The change in soil electric conductivity (EC), $\mathrm{pH}$ and bulk density (BD) in different reclamation treatments at the $0-20 \mathrm{~cm}$ and $20-40 \mathrm{~cm}$ soil depths were illustrated
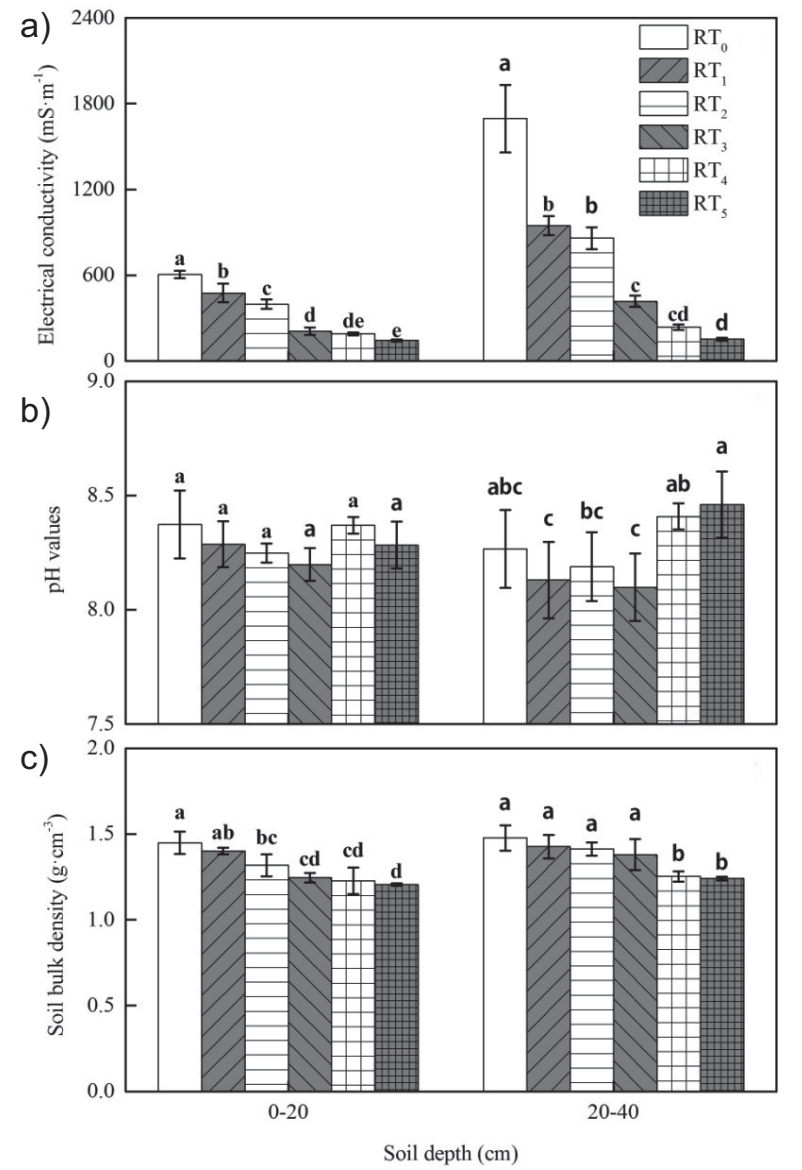

Fig. 3. Changes of soil electrical conductivity, $\mathrm{pH}$ and bulk density in different reclamation times at $0-20 \mathrm{~cm}$ and $20-\mathrm{cm}$ soil depth. Vertical bars represent $\pm S D$ of the mean $(n=4)$; Different letters on the SD bars indicate significant differences among the treatments $(\mathrm{p}<0.05)$.

in Fig. 3. The effects of RT on EC (Fig. 3a) and BD (Fig. 3c) given different reclamation histories followed the same trend as that of SS (Fig. 2). At the $0-20 \mathrm{~cm}$ soil depth, compared to RT0, different reclamation treatments (from RT5 to T36) decreased EC and BD by $21.4 \% \sim 76.3 \%$ and $3.4 \% \sim 16.8 \%$, respectively. At the

Table 2. The variance analysis of reclamation treatments on various physical and chemical properties of saline-sodic soils.

\begin{tabular}{|c|c|c|c|c|c|c|c|c|c|c|c|}
\hline & & $\mathrm{BD}$ & $\mathrm{SS}$ & $\mathrm{pH}$ & $\mathrm{EC}$ & $\mathrm{SOM}$ & $\mathrm{TC}$ & $\mathrm{TN}$ & $\mathrm{C} / \mathrm{N}$ ratio & $\mathrm{AP}$ & $\mathrm{AK}$ \\
\hline \multirow{3}{*}{$0-20 \mathrm{~cm}$} & $\mathrm{df}$ & 5 & 5 & 5 & 5 & 5 & 5 & 5 & 5 & 5 & 5 \\
\cline { 2 - 14 } & $\mathrm{F}$ & 2.56 & 64.83 & 0.96 & 89.45 & 95.35 & 18.25 & 157.97 & 468.11 & 224.42 & 22.55 \\
\cline { 2 - 13 } & $p$ & 0.081 & 0.000 & 0.478 & 0.000 & 0.000 & 0.000 & 0.000 & 0.000 & 0.000 & 0.000 \\
\hline \multirow{3}{*}{$20-40 \mathrm{~cm}$} & $\mathrm{df}$ & 5 & 5 & 5 & 5 & 5 & 5 & 5 & 5 & 5 & 5 \\
\cline { 2 - 12 } & $\mathrm{F}$ & 7.95 & 87.56 & 3.50 & 87.50 & 85.86 & 15.18 & 161.28 & 357.49 & 99.55 & 16.79 \\
\cline { 2 - 11 } & $p$ & 0.002 & 0.000 & 0.035 & 0.000 & 0.000 & 0.000 & 0.000 & 0.000 & 0.000 & 0.000 \\
\hline
\end{tabular}

BD-bulk density; EC-electrical conductivity; SS-soluble salts; TC-total carbon; TN-total nitrogen; C/N- soil carbon/ nitrogen; SOM-soil organic matter; AP-available phosphorus; AK-available potassium. 
Table 3. Changes of soil nutrient parameters under different reclamation treatments at 0-20 cm and 20-40 cm soil depth.

\begin{tabular}{|c|c|c|c|c|c|c|c|}
\hline \multirow[b]{2}{*}{$\begin{array}{l}\text { Soil depth } \\
\qquad(\mathrm{cm})\end{array}$} & \multirow[b]{2}{*}{$\begin{array}{l}\text { Reclaim } \\
\text { treatments }\end{array}$} & \multicolumn{6}{|c|}{ Soil parameters } \\
\hline & & $\begin{array}{l}\text { Soil organic } \\
\text { matter content } \\
\left(\mathrm{g} \cdot \mathrm{kg}^{-1}\right)\end{array}$ & $\begin{array}{c}\text { Soil total } \\
\text { carbon content } \\
\left(\mathrm{g} \cdot \mathrm{kg}^{-1}\right)\end{array}$ & $\begin{array}{c}\text { Soil total } \\
\text { nitrogen content } \\
\left(\mathrm{g} \cdot \mathrm{kg}^{-1}\right)\end{array}$ & $\begin{array}{l}\text { Soil } \mathrm{C} / \mathrm{N} \\
\text { ratio }(\%)\end{array}$ & $\begin{array}{c}\text { Soil available } \\
\text { potassium content } \\
\left(\mathrm{g} \cdot \mathrm{kg}^{-1}\right)\end{array}$ & $\begin{array}{c}\text { Soil available } \\
\text { phosphorus content } \\
\left(\mathrm{g} \cdot \mathrm{kg}^{-1}\right)\end{array}$ \\
\hline \multirow{6}{*}{$0-20 \mathrm{~cm}$} & RT0 & $6.2 \pm 0.08 \mathrm{e}$ & $13.2 \pm 0.6 \mathrm{~d}$ & $0.54 \pm 0.03 \mathrm{e}$ & $9.6 \pm 0.3 \mathrm{e}$ & $90.1 \pm 6.1 \mathrm{~d}$ & $0.71 \pm 0.02 \mathrm{~b}$ \\
\hline & RT5 & $9.2 \pm 0.83 \mathrm{~d}$ & $16.9 \pm 0.8 \mathrm{c}$ & $0.50 \pm 0.03 \mathrm{e}$ & $18.0 \pm 0.4 \mathrm{~d}$ & $92.4 \pm 2.6 \mathrm{~d}$ & $0.73 \pm 0.02 \mathrm{~b}$ \\
\hline & RT10 & $11.8 \pm 0.67 \mathrm{c}$ & $16.5 \pm 0.8 \mathrm{c}$ & $0.62 \pm 0.02 \mathrm{~d}$ & $21.0 \pm 0.4 \mathrm{c}$ & $146.3 \pm 4.3 \mathrm{c}$ & $0.81 \pm 0.03 \mathrm{~b}$ \\
\hline & RT15 & $15.0 \pm 0.34 \mathrm{ab}$ & $18.3 \pm 1.5 b c$ & $0.78 \pm 0.05 \mathrm{c}$ & $29.4 \pm 1.5 \mathrm{~b}$ & $156.2 \pm 4.3 \mathrm{~b}$ & $1.01 \pm 0.06 \mathrm{a}$ \\
\hline & RT27 & $15.6 \pm 1.09 \mathrm{a}$ & $19.7 \pm 1.5 \mathrm{ab}$ & $0.94 \pm 0.05 \mathrm{~b}$ & $39.6 \pm 1.7 \mathrm{a}$ & $186.3 \pm 4.0 \mathrm{a}$ & $1.13 \pm 0.12 \mathrm{a}$ \\
\hline & RT36 & $14.1 \pm 0.27 \mathrm{~b}$ & $21.2 \pm 1.2 \mathrm{a}$ & $1.37 \pm 0.07 \mathrm{a}$ & $39.2 \pm 0.6 \mathrm{a}$ & $149.8 \pm 4.5 \mathrm{c}$ & $1.14 \pm 0.10 \mathrm{a}$ \\
\hline \multirow{6}{*}{$20-40 \mathrm{~cm}$} & RT0 & $5.1 \pm 0.02 \mathrm{~d}$ & $12.0 \pm 0.6 \mathrm{~d}$ & $0.34 \pm 0.02 \mathrm{~d}$ & $10.9 \pm 0.0 \mathrm{e}$ & $70.3 \pm 4.8 \mathrm{e}$ & $0.68 \pm 0.01 \mathrm{c}$ \\
\hline & RT5 & $8.3 \pm 0.64 \mathrm{c}$ & $16.3 \pm 0.8 \mathrm{bc}$ & $0.30 \pm 0.04 \mathrm{~d}$ & $24.0 \pm 1.1 \mathrm{~d}$ & $80.9 \pm 2.9 \mathrm{~d}$ & $0.70 \pm 0.01 \mathrm{c}$ \\
\hline & RT10 & $8.1 \pm 0.43 \mathrm{c}$ & $15.1 \pm 0.9 \mathrm{c}$ & $0.50 \pm 0.03 \mathrm{c}$ & $31.6 \pm 1.2 \mathrm{c}$ & $127.5 \pm 3.5 \mathrm{a}$ & $0.69 \pm 0.01 \mathrm{c}$ \\
\hline & RT15 & $11.4 \pm 0.42 \mathrm{a}$ & $16.9 \pm 0.8 \mathrm{abc}$ & $0.48 \pm 0.01 \mathrm{c}$ & $33.9 \pm 0.4 \mathrm{c}$ & $110.2 \pm 4.8 \mathrm{~b}$ & $0.83 \pm 0.06 \mathrm{a}$ \\
\hline & RT27 & $11.5 \pm 0.07 \mathrm{a}$ & $18.3 \pm 1.7 \mathrm{a}$ & $0.68 \pm 0.06 \mathrm{~b}$ & $60.4 \pm 3.4 \mathrm{a}$ & $111.9 \pm 2.1 \mathrm{~b}$ & $0.80 \pm 0.02 \mathrm{ab}$ \\
\hline & RT36 & $10.4 \pm 0.60 \mathrm{~b}$ & $17.5 \pm 0.9 \mathrm{ab}$ & $1.10 \pm 0.05 \mathrm{a}$ & $51.4 \pm 1.5 \mathrm{~b}$ & $99.3 \pm 3.2 \mathrm{c}$ & $0.78 \pm 0.01 \mathrm{~b}$ \\
\hline
\end{tabular}

Different letters indicate significant differences $(p<0.05)$ between water treatments according Duncan test. Values shown are means \pm standard deviation (SD) of four replicates.

$20-40 \mathrm{~cm}$ soil depth, the decrease percent in EC and BD were 44.2 91.0 and 3.5 16.0, respectively. In the same reclamation treatment, $\mathrm{EC}$ and $\mathrm{BD}$ at the $0-20 \mathrm{~cm}$ soil depth were smaller than those at the $20-40 \mathrm{~cm}$ soil depth. However, the soil $\mathrm{pH}$ exhibited different changes in the different reclamation treatments. As shown in Fig. 3b), the soil $\mathrm{pH}$ was alkaline and ranged from 8.10 to 8.46 . The $\mathrm{pH}$ values at the $0-20 \mathrm{~cm}$ soil depth in the different reclamation treatments were not significant ( $p>0.05$ ). At the $20-40 \mathrm{~cm}$ soil depth, compare to that in RT0, the soil pH in RT5, T10, T15 decreased by $1.7 \%$, $0.9 \%, 2.0 \%$, respectively, and that in T27, T36 increased by $2.7 \%$ and $3.3 \%$, respectively.

\section{Soil Nutrient Content}

The nutrient balance of terrestrial ecosystems can remarkably change due to anthropogenic activities. The contents of SOM, TC, TN, C/N ratio, AK and $\mathrm{AP}$ in the different reclamation treatments at $0-20 \mathrm{~cm}$ and $20-40 \mathrm{~cm}$ soil depth were shown in Table 3. Soil nutrient properties varied between the reclaimed chronosequence of 5 to 36 years and natural sites. At the $0-20 \mathrm{~cm}$ soil depth, of the treatments, RT0 had the lowest values of all soil nutrient contents. With the increase of reclamation times, the soil nutrient contents significantly increased. After 27 to 36 years of reclamation, SOM, TC, C/N ratio and AK in RT27 had the highest values, which were higher than those in RT0 by $151.6 \%, 49.2 \%, 312.5 \%$ and $106.8 \%$, respectively, where the TC and AP in TR36 had the highest values, which were higher than those inT0 by $60.6 \%$ for both.
With increasing soil depth, the effect of soil nutrient contents at the $20-40 \mathrm{~cm}$ soil depth in the different reclamation treatments exhibited similar trends at the $0-20 \mathrm{~cm}$ soil depth. The contents of SOM, TC, C/N ratio, $\mathrm{AP}$ and $\mathrm{AK}$ in TR27 and TN at TR36 were higher than those in the other treatments.

Although the change in soil nutrient content at the $20-40 \mathrm{~cm}$ soil depth was similar to that at $0-20 \mathrm{~cm}$ soil depth, all the nutrient properties (except the $\mathrm{C} / \mathrm{N}$ ratio) of saline-sodic soil at all reclaimed (RT5 to R36) and natural (CK) sites decreased with increasing soil depth (Table 3). Compare to topsoil fertility, nutrient parameters such as SOM, TC, TN, AK and AP at the $20-40 \mathrm{~cm}$ soil depth decreased up to $9.8 \% \sim 31.4 \%, \quad 3.6 \% \sim 17.5, \quad 19.4 \% \sim 38.5 \%, \quad 12.4 \% \sim 39.9 \%$ and $4.1 \% \sim 31.6 \%$, respectively. The change in the $\mathrm{C} / \mathrm{N}$ ratio exhibited the opposite trend of the other nutrient parameters and increased by $13.5 \% \sim 50.5 \%$ at the 20-40 cm soil depth.

\section{Relationship Among Soil Properties}

The relationship among the different soil properties is shown in Fig. 4. $\mathrm{pH}$ only had significant positively correlations with $\mathrm{TN}\left(\mathrm{R}^{2}=0.34\right)$ and $\mathrm{C} / \mathrm{N}\left(\mathrm{R}^{2}=0.35\right)$ and a negative relationship with $\mathrm{BD}\left(\mathrm{R}^{2}=0.46\right)$. Except for $\mathrm{pH}$, the other soil properties had significant correlations $(p<0.01)$ with each other. SS was positively correlated with $\mathrm{BD}$ and $\mathrm{EC}(p<0.01)$ but has a negative relationship with all soil fertility parameters, such as $\mathrm{SOM}, \mathrm{TC}, \mathrm{TN}$, the $\mathrm{C} / \mathrm{N}$ ratio, $\mathrm{AP}$ and AK. The soil nutrient parameters had significant 


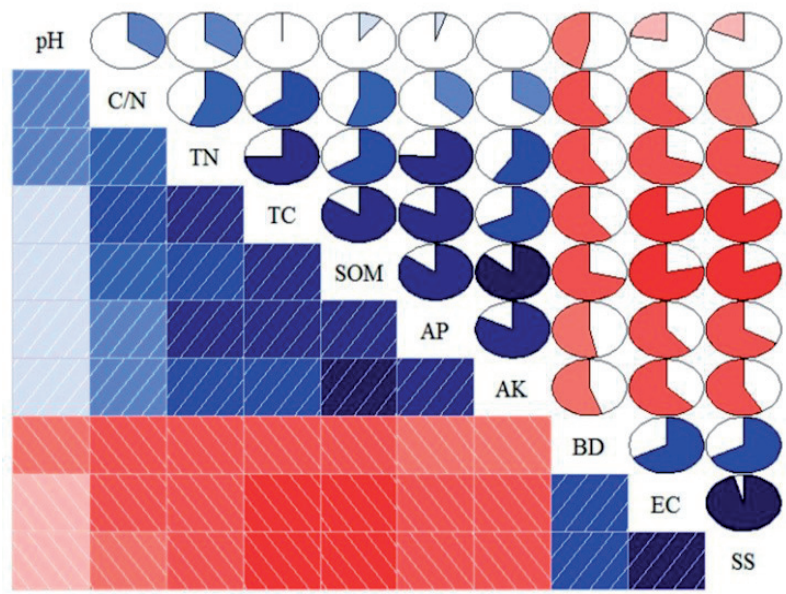

Fig. 4. Pearson's correlation coefficients among soil physical and chemical properties. The figure is plotted by R Programming Language software. Red colour in the rectangles and circles indicates a negative relationship between different properties; blue colour in the rectangles and circles indicates a negative relationship between different properties; the darker red or blue colour indicates a more close relationship.

positively correlations $(p<0.01)$ with each other, but the relationship with $\mathrm{BD}$ was significantly negatively.

\section{Discussion}

Soluble salts have been proved to be an influenceable variable in inhibiting plant seedling survival and growth, and crop productivity decreases with increasing soluble salt concentration [11, 31]. In our study, at the beginning of the reclamation ages, the soil salt contents were $2.9 \sim 5.2 \%$ (Fig. 2) which could severely restrict plant growth survival [32]. However, with increasing reclamation time, soil salinity decreased sharply, suggesting that reclamation activities were very useful for the utilization of saline-sodic soils [33]. Yan et al. (2015) also found that soil salinity declined consecutively with reclamation time [34]. After decades of reclamation, the change in soil salt is smaller (Fig. 2) than that at the beginning. Base to our results, we hypothesis that there may be a relationship between the reclamation time and SS. A generalized linear model was used to express the relationship between the reclamation time and SS (Fig. 5). The change in the regulation of SS with RT was expressed by the follow function: $\mathrm{SS}=-222.9+\frac{225.8}{1+\left(\frac{\mathrm{RT}}{1.34 \times 10^{7}}\right)^{0.37}}\left(\mathrm{R}^{2}=0.93\right.$, $p<0.01)$ at the $0-20 \mathrm{~cm}$ soil depth, and $\mathrm{SS}=0.82+\frac{4.48}{1+\left(\frac{\mathrm{RT}}{10.6}\right)^{1.57}}\left(\mathrm{R}^{2}=0.97, p<0.01\right)$ at the

$20-40 \mathrm{~cm}$ soil depth. The close relationship between reclamation age and SS may provide a theoretical direction in the amelioration of coastal saline-sodic soils.

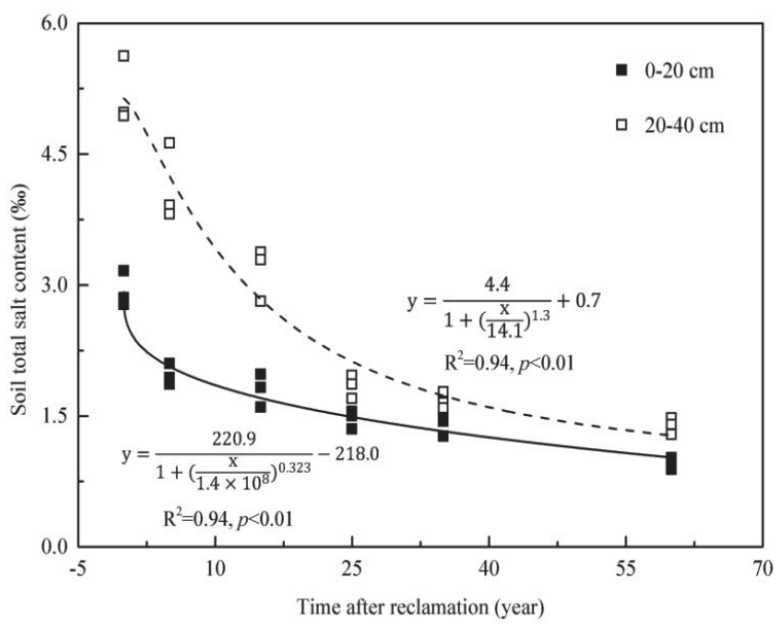

Fig. 5. Fitted non-linear curves between soil salt contents and reclamation times.

Soil EC is considered to be an integrated indicator for soil physical and chemical properties that are strongly related to crop yield, and soil extract EC could be used to reflect soil salinity levels [35]. Increased EC, which is significantly influenced by applied soil amendments, has adverse effects on soil structural stability, bulk density, and permeability [36]. In our study, EC decreased with increasing reclamation histories and soil layers and exhibited a similar trend to the change in SS. The results further verified the ameliorating impact of reclamation on coastal salinesodic soils. Soil BD could be used as a significant indicator of soil structure change with different years of reclamation patterns. Shrestha and Lal (2011) estimated that the BD within one year of reclamation significantly decreased by $6 \%$ to $54 \%$ compared to that of adjacent undisturbed soils [37]. Our study showed similar results: $\mathrm{BD}$ was significantly higher $(p<0.001)$ at the undisturbed site $\left(1.45-1.48 \mathrm{~g} \cdot \mathrm{cm}^{-3}\right.$ than at the reclaimed sites and increased with soil depths. The decrease in $\mathrm{BD}$ after reclamation activity observed in the present study could be explained by the use of fertilizer and soil tillage with agricultural equipments. The result contradicts to those reported by Ezeokoli et al. (2020), who did not observe any significant changes in $\mathrm{BD}$ at a $0-30 \mathrm{~cm}$ depth in reclamation soil compared with that in undisturbed soil because heavy equipments compacted the soils [38]. Soil $\mathrm{pH}$ plays an important role in ecological restoration owing to its function in moderating the availability of plant nutrients. Severe soil disturbance inevitably causes changes in soil $\mathrm{pH}$, usually resulting in a decreased $\mathrm{pH}$ [39]. A similar observation of an increase in soil $\mathrm{pH}$ after reclamation, from a near neutral value of 8.78 to a slightly basic status of 7.95, was also reported by Cheng and his collaborators (2018) [40]. In our study, the $\mathrm{pH}$ slightly decreased after reclamation (Fig. 3), but the difference was not significantly (Table 2). The decrease in $\mathrm{pH}$ was probably due to the change in SOC after reclamation, 


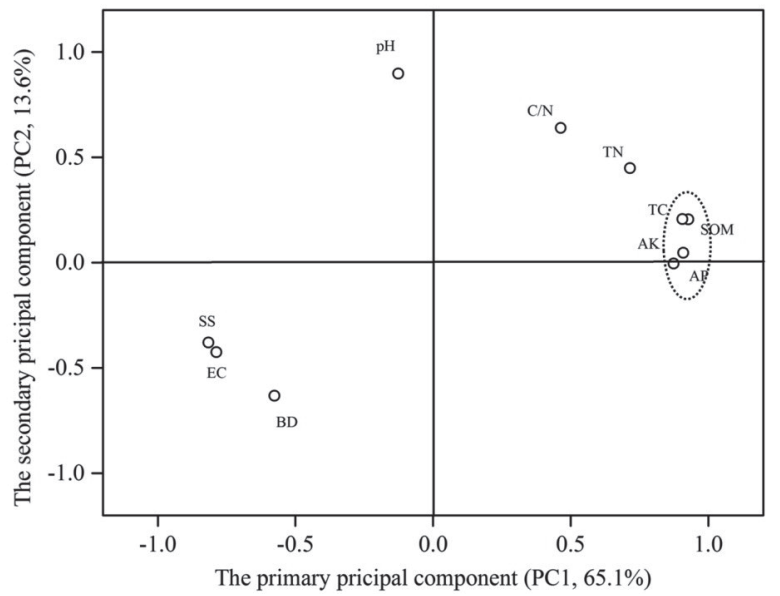

Fig. 6. Principal component analysis ordinations of soil properties.

which could have results in the extraction of base cations from the soil and the release of protons into the soil [41]. However, based on the correlation analysis, $\mathrm{pH}$ had a poor relationship with SOM and a significant positive relationship with TN (Fig. 4) in our research. The influence of soil nitrogen on $\mathrm{pH}$ may have played a more important role than soil carbon at our study site.

Many studies have shown that reclamation activities played a key role in nutrient stocks and that soil fertility decreases with soil depth and increases with reclamation age [14, 18]. By the study of Ahirwal (2017), soil C and N stocks were more pronounced in the topsoil than in other soil layers and increased over time, with an approximately two-thirds increase after 7-11 years of reclamation [42]. However, Zhang et al (2015) reached a different conclusion that the $\mathrm{N}$ and $\mathrm{C}$ concentrations increased with soil depth, while the highest $\mathrm{P}$ concentration was observed in the uppermost soil [12]. Tan and Kang (2009) also found that after the restoration of natural salt-affected land, total $\mathrm{P}$ content changed only in the topsoil [43]. At our site, soil fertility indices such as SOM, TC, TN, AP and AK was significantly different among all reclamation sites and were positively associated with reclamation time but decreased with the soil depth overall in the fellow order: 36-year reclaimed soils $>7$-year reclaimed soils $>$ 15 -year reclaimed soils $>10$-year reclaimed soils $>5$-year reclaimed soils $>$ undisturbed saline-sodic soils. Sun et al. (2011) conducted an experiment on the Southern Shanghai coast of China also found that SS, SOC, AP and soil nitrate nitrogen $\left(\mathrm{NO}_{3}-\mathrm{N}\right)$ were correlated with time after reclamation and became relatively stable after approximately 35 years [44].

The ranges of SOM, TC, TN, AP, and $\mathrm{AK}$ in the reclaimed saline-sodic soils were larger than those in the natural soils (Table 2). Reclaimed soil fertility increased with the age of reclamation and decreased with soil depth, which may have been attributable to the changes in soils characteristics and plant growth [42]. Bu's result indicated that reclamation significantly affected soil water conditions and then greatly altered soil $\mathrm{C}$ dynamics with the transition from salt marshes to reclaimed lands [45]. The SOM concentration in the topsoil was significantly higher than that in the deeper layers in both the natural soils and reclaimed soils, which may have been attributable to the conversion from leaf litter fall to humus in the topsoil [46]. It has been found that reclamation activities could help to increase the proportion of soil aggregates and could reduce the loss of soil nutrients from tillage practices and irrigation [47], which may be one reason why P and $\mathrm{K}$ increased throughout the soil profile after reclamation [48]. The $\mathrm{C} / \mathrm{N}$ ratio is a good indicator that can be used to characterize the decomposition degree of organic matter and the quality of soil organic matter and to identify the terrestrial-based or marine-based sources of soil organic matter and nitrogen limitation of plants in terrestrial ecosystems [49]. The higher the $\mathrm{C} / \mathrm{N}$ ratio was, the lower the degree of decomposition of organic matter [50]. Similar to the information in Ahirwal's conclusion on mine soils, the $\mathrm{C} / \mathrm{N}$ ratio increased with both reclamation ages in our study, indicating that reclamation is favorable to external $\mathrm{C}$ source input, which affected $\mathrm{N}$ metabolism, and that reclaimed salinesodic land can act as a source/sink of $\mathrm{CO}_{2}$ in terrestrial ecosystems, playing an important role in offsetting the increased emissions of greenhouse gases [42].

The changes in soil parameters with soil depth and reclamation ages generally followed similar patterns (Table 2) indicating that each of the parameters was intimately linked [19]. However, it was difficult to determine the relative important factors because reclamation activities effect many physical and chemical properties of coastal saline-sodic soils. To address this problem, principal component analysis (PCA) was employed in our study (Fig. 6) to figure out the soil limiting factors. PCA a method to regroup numerous correlation indices into a new set of independent composite indices to replace the original indices and to derive a soil quality index that can be used for assess the progress of reclamation [19]. In this method, the first selected linear combination (F1) variance was used to represent the set, and the larger the variance (F1) is, the more information is contained in F1 [37]. Then, a new set of composite indices was created as linear combinations of the original ten indices in our study. As shown in Fig. 6, the primary principal component (PC1) reflects $65.1 \%$ of the total information, while the secondary principal component (PC2) reflects $13.6 \%$ of the total information. $\mathrm{PC} 1$ was positively correlated with SOM, TC, AP and AK; PC2 was positively correlated with $\mathrm{pH}$. Based on the above analysis, the soil nutrient characteristics (SOM, TC, $\mathrm{AP}$ and $\mathrm{AK}$ ) and $\mathrm{pH}$ are the limiting soil factors that need further study. 


\section{Conclusion}

In conclusion, there is high temporal-spatial variability in the physical and chemical properties distributed within reclaimed agricultural lands with different reclamation histories and soil depths. Reclamation activity is proven to be an effective way to inhibit soil salts and improve soil fertilization. The ameliorating effect of different reclamation times on saline-sodic soil was in the order: 36-year reclaimed soils $>27$-year reclaimed soils $>15$-year reclaimed soils $>10$-year reclaimed soils $>5$-year reclaimed soils $>$ undisturbed saline-sodic soils. The effect of reclamation on saline-sodic soils primary occurs in topsoil. According to the results of PCA, the soil nutrient characteristics ( $\mathrm{SOM}, \mathrm{TC}, \mathrm{AP}$ and $\mathrm{AK}$ ) and $\mathrm{pH}$ may play a limiting role in the amelioration of reclamation on physical and chemical properties of coastal salinesodic soils.

\section{Acknowledgements}

This work was supported by the National Key Research and Development Project [grant number 2017YFD0800602].

\section{Conflict of Interest}

The authors declare no conflicts of interest.

\section{References}

1. LI J., PU L., HAN M., ZHU M., ZHANG R., XIANG Y. Soil salinization research in China: Advances and prospects. Journal of Geographical Sciences, 24, 943, 2014.

2. YAMATO M., YAGAME T., YOSHIMURA Y., IWASE $\mathrm{K}$. Effect of environmental gradient in coastal vegetation on communities of arbuscular mycorrhizal fungi associated with Ixeris repens (Asteraceae). Mycorrhiza, 22, 623, 2012.

3. MENG Q., YANG J., YAO R., LIU G. Soil quality in east coastal region of China as related to different land use types. Journal of Soils and Sediments, 13, 664, 2013

4. YAZDANPANAH N., PAZIRA E., NESHAT A., MAHMOODABADI M., SINOBAS L.R. Reclamation of calcareous saline sodic soil with different amendments (II): Impact on nitrogen, phosphorous and potassium redistribution and on microbial respiration. Agricultural Water Management, 120, 39, 2013.

5. HU H., LIU H., LIU F. Seed germination of hemp (Cannabis sativa L.) cultivars responds differently to the stress of salt type and concentration. Industrial Crops and Products. 123, 254, 2018.

6. FENG G., ZHANG F., LI X., TIAN C., TANG C., RENGEL Z. Improved tolerance of maize plants to salt stress by arbuscular mycorrhiza is related to higher accumulation of soluble sugars in roots. Mycorrhiza, 12, 185, 2002.
7. METHENY N.A., KRIEGER M.M. Salt Toxicity: A Systematic Review and Case Reports. Journal of Emergency Nursing, 46, 428, 2020.

8. PARIHAR M., RAKSHIT A., RANA K., PRASAD MEENA R., CHANDRA JOSHI D. A consortium of arbuscular mycorrizal fungi improves nutrient uptake, biochemical response, nodulation and growth of the pea (Pisum sativum L.) under salt stress. Rhizosphere, 15, 100235, 2020.

9. LIANG W., MA X., WAN P., LIU L. Plant salt-tolerance mechanism: A review. Biochemical and Biophysical Research Communications, 495, 286, 2018.

10. SLAMA I., ABDELLY C., BOUCHEREAU A., FLOWERS T., SAVOURÉ A. Diversity, distribution and roles of osmoprotective compounds accumulated in halophytes under abiotic stress. Annals of botany, 115, 433, 2015.

11. YAHYAZADEH M., MEINEN R., HÄNSCH R., ABOUZEID S., SELMAR D. Impact of drought and salt stress on the biosynthesis of alkaloids in Chelidonium majus L. Phytochemistry, 152, 204, 2018.

12. ZHANG T., WANG T., LIU K.S., WANG L., WANG K., ZHOU Y. Effects of different amendments for the reclamation of coastal saline soil on soil nutrient dynamics and electrical conductivity responses. Agricultural Water Management, 159, 115, 2015.

13. OLSEN S.R., SOMMERS L.E.. PHOSPHORUS. In: Page, A.L. and Miller, R.H., Eds., Methods of Soil Analysis, Part 2, $2^{\text {nd }}$ Edition, Agronomy Monograph 9, ASA and SSSA, Madison, 1982.

14. XU E., ZHANG H., XU Y. Exploring land reclamation history: Soil organic carbon sequestration due to dramatic oasis agriculture expansion in arid region of Northwest China. Ecological Indicators, 108, 105746, 2020.

15. GE B., CUI J., ZHANG D., LIU Q., JIANG S., TANG B., YANG L., ZHOU C. Succession of soil macro-faunal biodiversity in forests converted from croplands after longterm coastal reclamation. Soil and Tillage Research, 186, $165,2019$.

16. TRIPATHI N., SINGH R.S., HILLS C.D. Soil carbon development in rejuvenated Indian coal mine spoil. Ecological Engineering, 90, 482, 2016.

17. ILYAS M., QURESHI R.H., QADIR M.A. Chemical changes in a saline-sodic soil after gypsum application and cropping. Soil Technology, 10, 247, 1997.

18. QIANG W., YANG B., LIU Y., QI K., YANG T., PANG X. Effects of reclamation age on soil microbial communities and enzymatic activities in the sloping citrus orchards of southwestern China. Applied Soil Ecology, 152, 103566, 2020.

19. MUKHOPADHYAY S., MAITI S.K., MASTO R.E. Development of mine soil quality index (MSQI) for evaluation of reclamation success: A chronosequence study. Ecological Engineering, 71, 10, 2014.

20. YAO R., YANG J., GAO P., ZHANG J., JIN W. Determining minimum data set for soil quality assessment of typical salt-affected farmland in the coastal reclamation area. Soil and Tillage Research, 128, 137, 2013.

21. LU Q., BAI J., ZHANG G., WU J. Effects of coastal reclamation history on heavy metals in different types of wetland soils in the Pearl River Delta: Levels, sources and ecological risks. Journal of Cleaner Production, 272, $122668,2020$.

22. MENG W., HU B., HE M., LIU B., MO X., LI H., WANG Z., ZHANG Y. Temporal-spatial variations and driving 
factors analysis of coastal reclamation in China. Estuarine, Coastal and Shelf Science, 191, 39, 2017.

23. CUI BS, YANG Q.C., YANG Z.F., ZHANG K.J. Evaluating the ecological performance of wetland restoration in the Yellow River Delta, China. Ecological Engineering, 35, 1090, 2009.

24. FAN X., PEDROLI B., LIU G., LIU Q., LIU H., SHU L. Soil salinity development in the yellow river delta in relation to groundwater dynamics. Land Degradation \& Development, 23, 175, 2012.

25. LIU C., DAI Z., XIA J., CHANG C., SUN H. Combined effect of salt and drought on boron toxicity in Puccinellia tenuiflora. Ecotoxicology and Environmental Safety, 157, 395, 2018.

26. XIAO L., XIE B., LIU J., ZHANG H., HAN G., WANG O., LIU F. Stimulation of long-term ammonium nitrogen deposition on methanogenesis by Methanocellaceae in a coastal wetland. Science of the Total Environment, 595, 337, 2017.

27. LI X., XIA J., ZHAO X., CHEN Y. Effects of planting Tamarix chinensis on shallow soil water and salt content under different groundwater depths in the Yellow River Delta. Geoderma, 335, 104, 2019.

28. YANG Z.P., ZHENG S.X., NIE J., LIAO Y.L., XIE J. Effects of long-term winter planted green manure on distribution and storage of organic carbon and nitrogen in water-stable aggregates of reddish paddy soil under a double-rice cropping system. Journal of Integrative Agriculture, 13, 1772, 2014.

29. TISDALL J.M., OADES J.M. Organic matter and waterstable aggregates in soils. Journal of soil science 33, 141, 1982.

30. MEBIUS L.J. A rapid method for the determination of organic carbon in soil. Analytica Chimica Acta, 22, 120, 1960.

31. JACKSON K.W., LU S. Atomic Absorption, Atomic Emission, and Flame Emission Spectrometry. Analytical Chemistry, 70, 363, 1980.

32. ARIF Y., SINGH P., SIDDIQUI H., BAJGUZ A., HAYAT S. Salinity induced physiological and biochemical changes in plants: An omic approach towards salt stress tolerance. Plant Physiology and Biochemistry, 156, 64, 2020.

33. LI X., KANG Y., WAN S., CHEN X., LIU S., XU J. Response of a salt-sensitive plant to processes of soil reclamation in two saline-sodic, coastal soils using drip irrigation with saline water. Agricultural Water Management, 164, 223, 2016.

34. YAN N., MARSCHNER P., CAO W., ZUO C., QIN W. Influence of salinity and water content on soil microorganisms. International Soil and Water Conservation Research, 3, 316, 2015.

35. MUCHATE N.S., NIKALJE G.C., RAJURKAR N.S., SUPRASANNA P., NIKAM T.D. Physiological responses of the halophyte Sesuvium portulacastrum to salt stress and their relevance for saline soil bio-reclamation. Flora - Morphology, Distribution, Functional Ecology of Plants, 224, 96, 2016.

36. MAHMOODABADI M., YAZDANPANAH N., SINOBAS L.R., PAZIRA E., NESHAT A. Reclamation of calcareous saline sodic soil with different amendments
(I): Redistribution of soluble cations within the soil profile. Agricultural Water Management, 120, 30, 2013.

37. SHRESTHA R.K., LAL R. Changes in physical and chemical properties of soil after surface mining and reclamation. Geoderma, 161, 168, 2011.

38. EZEOKOLI O.T., MASHIGO S.K., MABOETA M.S., BEZUIDENHOUT C.C., KHASA D.P., ADELEKE R.A. Arbuscular mycorrhizal fungal community differentiation along a post-coal mining reclamation chronosequence in South Africa: A potential indicator of ecosystem recovery. Applied Soil Ecology, 147, 103429, 2020.

39. WANG X., YANG J., XIE X., CHEN X., PU L., ZHANG $\mathrm{X}$. Soil microbial succession with soil development since costal reclamation. Catena, 187, 104393, 2020.

40. CHENG Z., CHEN Y., ZHANG F. Effect of reclamation of abandoned salinized farmland on soil bacterial communities in arid northwest China. Science of The Total Environment, 630, 799, 2018.

41. BREEMEN N.V., DRISCOLL C.T., MULDER J. Acidic deposition and internal proton sources in acidification of soils and waters. Nature, 17, 241, 1984.

42. AHIRWAL J., MAITI S.K., SINGH A.K. Changes in ecosystem carbon pool and soil $\mathrm{CO}_{2}$ flux following postmine reclamation in dry tropical environment, India. Science of The Total Environment, 583, 153, 2017.

43. TAN J.L., KANG Y.H. Changes in soil properties under the influences of cropping and drip irrigation during the reclamation of severe salt-affected soils. Journal of Integrative Agriculture, 8, 1228, 2009.

44. SUN Y., LI X., MANDER Ü., HE Y., JIA Y., MA Z., GUO W., XIN Z. Effect of reclamation time and land use on soil properties in Changjiang River Estuary, China. Chinese Geographical Science, 21, 403, 2011.

45. BU N.S., QU J.F., LI G., ZHAO B., ZHANG R.J., FANG C.M. Reclamation of coastal salt marshes promoted carbon loss from previously-sequestered soil carbon pool. Ecological Engineering, 81, 335, 2015.

46. LIU X., BAI Z., ZHOU W., CAO Y., ZHANG G. Changes in soil properties in the soil profile after mining and reclamation in an opencast coal mine on the Loess Plateau, China. Ecological Engineering, 98, 228, 2016.

47. XU C., PU L., LI J., ZHU M. Effect of reclamation on $\mathrm{C}, \mathrm{N}$, and $\mathrm{P}$ stoichiometry in soil and soil aggregates of a coastal wetland in eastern China. Journal of Soils and Sediments, 19, 1215, 2019.

48. XIE X., PU L., WANG Q., ZHU M., XU Y., ZHANG M. Response of soil physicochemical properties and enzyme activities to long-term reclamation of coastal saline soil, Eastern China. Science of Total Environment, 607, 1419, 2017.

49. WANG J., BAI J., ZHAO Q., LU Q., XIA Z. Five-year changes in soil organic carbon and total nitrogen in coastal wetlands affected by flow-sediment regulation in a Chinese delta. Scientific reports, 6, 21137, 2016.

50. XU Y., PU L., LIAO Q., ZHU M., YU X., MAO T., XU C. Spatial variation of soil organic carbon and total nitrogen in the coastal area of mid-eastern China. International journal of environmental research and public health, 14, 780, 2017. 
